
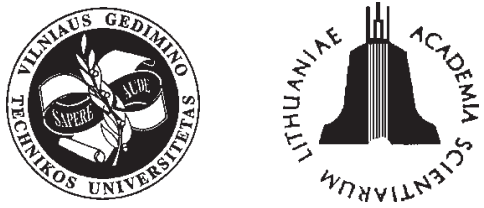

ISSN 1392-3730 print / ISSN 1822-3605 online

JOURNAL OF CIVIL ENGINEERING AND MANAGEMENT

http:/www.jcem.vgtu.lt

2006, Vol XII, No 1, 63-68

\title{
THE OPTIMISATION OF ENERGY SYSTEMS BY USING 3E FACTOR: THE CASE STUDIES
}

\author{
Artur Rogoža, Kęstutis Čiuprinskas, Giedrius Šiupšinskas \\ Dept of Heating and Ventilation, Vilnius Gediminas Technical University, \\ Sauletekio al.11,LT-10223Vilnius-40,Lithuania.E-mail:artur.rogoza@ap.vtu.lt
}

Received 18 April 2005; accepted 02 Dec 2005

\begin{abstract}
Energy systems should be analysed according to principles of sustainable development. The optimality of technical systems usually is evaluated by only technical and economical criteria. But the estimation of these criteria is not comprehensive enough in the case when system life cycle is much longer than the period of reliable economical prognosis. In this paper the criteria set of energy system evaluation and optimisation was expanded by energy and ecological standpoints and a new multiple criteria indicator (3E factor - Energy, Economy, Ecology) was introduced. The application of this factor was demonstrated by two examples: optimisation of the district heating network pipeline replacement periodicity and optimisation of the thermal insulation of the single family house.
\end{abstract}

Keywords: energy systems, optimisation, multi-criteria, sustainability, life cycle, district heating networks, thermal insulation.

\section{Introduction}

Sustainability is one of the newest principles of development of energy systems. Generally, the development of any major system created or operated by a human should be sustainable, but the energy systems influence a total sustainability particularly. Mostly, finite resources determine the sustainable development from one side and environmental pollution - from another. Essentially, sustainable system can be defined as "a set of integrated industrial and ecological processes that equitably meets the biophysical needs of society while maintaining the integrity of life-supporting ecosystems over a long-term time horizon" [1]. Therefore the sustainability of system development can be expressed as the best for a long lifetime. Obviously, this period should be not shorter than lifespan of the system, because all aspects associated with this system should be evaluated from the system creation, during its lifetime, till its destruction or utilisation of its elements. The method like this is named Life Cycle Analysis (LCA). It is a complicated enough method of analysis, which needs to evaluate many different factors. Perhaps therefore it has been applied for simple packaging materials foremost. Analysing complex and long-lived systems, the life cycle of which covers some decades, economic forecast cannot be surely done. Exceptionally it is typical of the countries of transition period, what corresponds to conversion of economical system. Then the better way is to use not only economical factors but also physical criterions, which depend neither on economical nor political conditions.
The essential standpoint of this work is a multiple criteria optimisation. Three criteria were used in the case studies - energy demand, expenses and environmental pollution. The factor defining them together was named 3E (Energy, Economy, Ecology) [2]. In principle, evaluating any system, a number of criteria can be much greater, but we are of the opinion that the aforesaid criteria express the best matter of energy system sustainability.

\section{Fundamental methodology}

In this paper described examples differ by type of energy system. In the first case it is energy distribution system represented by heat supply network, in the second - energy consuming system represented by a singlefamily house. These systems as well as energy generation (transformation) system (not analysed in this work) can be treated as subsystems of wider system - buildings energy system (Fig 1). This system is closely linked with environment. Energy could be treated as an input of this system, and pollution - as output. In order to be named as „sustainable“, this system should be optimal from the point of view of energy and pollution. Naturally, to be not only a theoretical model, the system should also be reasonable economically. Here the optimality means minimal energy expenditures, environment pollution and expenses during all the life cycle of the system. Each individual subsystem, as well as the whole energy system can be analysed by the same prin- 


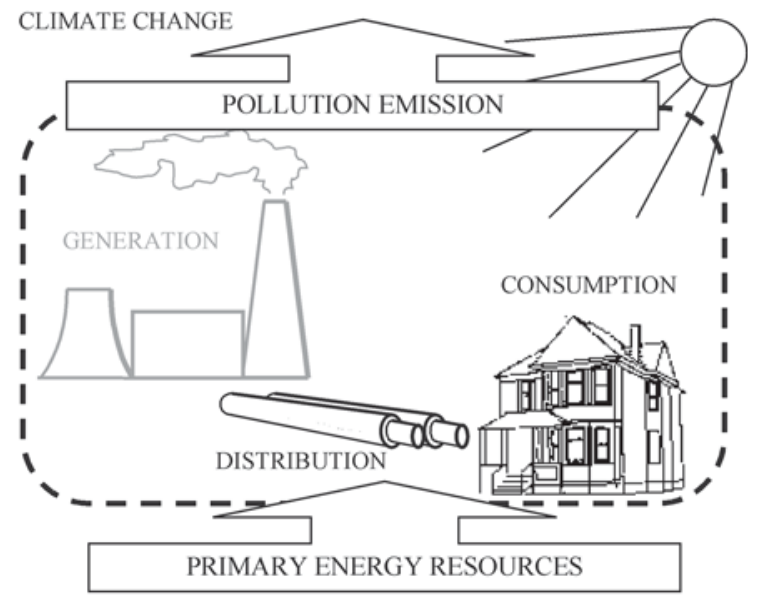

Fig 1. The buildings energy system

ciples. In this work it is multiple criteria (3E factor) optimisation of the investigated system during its life cycle.

\section{Description of the case studies}

\subsection{Optimisation of the district heating (DH) network maintenance}

The goal of this study was to evaluate the efficiency of maintenance works during the period of DH network lifetime in energy, economical and ecological standpoints, and to determine the most reasonable periodicity of preventive repairs. For this purpose a special methodology was prepared and data for energy, economical and ecological estimation of the network were collected, a life cycle and a depreciation models were prepared and tested on DH networks of Zarasai, as well as results of the calculations were evaluated. A similar study was prepared before [3] by using two factors - energy and economy.

In this case study the object of the research is a DH network in Zarasai town (Lithuania). District heating system in Zarasai consists of three networks for which the heat is supplied from three boiler houses. Two networks are investigated in this work. Those networks belong to boiler houses RK-1 and RK-2. Total heat load of them is $20 \mathrm{MW}$, and the main fuel combusted in the boilers is a crude oil. The networks are four-pipe assembled in concrete channels pipelines what are planned to change in a two-pipe pre-insulated buried pipes. Therefore, those networks were calculated as two-pipe preinsulated buried pipelines. The pipes of the networks haven't been renewed periodically. Separate pipe sections have been replaced in a case of leak, consequently at this time the network is worn out, and average age of the pipes is 21 year. Total length of the pipelines is about $6 \mathrm{~km}$, their diameters range from 25 to $200 \mathrm{~mm}$. The heated area of the buildings, what belong to those networks, is about $111000 \mathrm{~m}^{2}$.
Two main methods of assessment were used in the task - life cycle analysis and multiple criteria analysis $[4,5]$. Using the method of life cycle analysis primary energy demand and pollution amount corresponding a life cycle of a particular object can be estimated. In this case life cycle analysis was used for a calculation of primary energy demand and $\mathrm{CO}_{2}$ emission for production of materials needed for construction and maintenance of $\mathrm{DH}$ network.

All three indicators of the assessment - energy, expenses and $\mathrm{CO}_{2}$ emission, were calculated for preventive maintenance, emergency repairs and heat losses in the networks. The preventive maintenance is definable as preventive repairs of a separate pipe sections, ie a replacement of old pipes by new ones. The estimation of a periodicity of the replacement of worn-out pipe sections is characterised as the goal of the work. The concept of emergency was used evaluating the leaks in the networks. The amounts of elimination of the leaks depend on accident rate in the pipes of a particular age, therefore an analysis of accident rate in Lithuanian DH networks was carried out. According to this analysis, the equation of average accident rate dependent on a pipe age was created [6]. Classical methodology [7] was used for calculation of heat losses in pre-insulated buried pipes, however in this case the depreciation of insulation was evaluated additionally [8]. It results in the increase of heat losses in time. Graphical interpretation of optimisation of pipeline lifetime is taken in Fig 2.

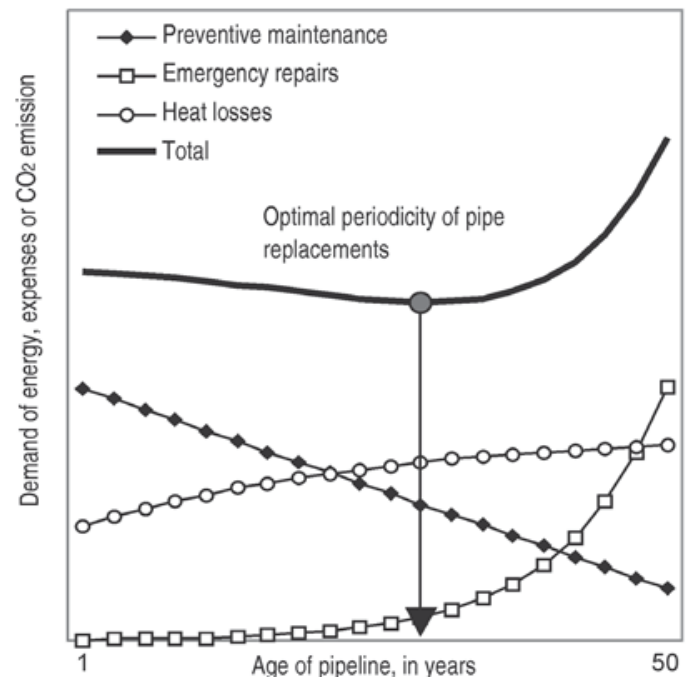

Fig 2. Principal scheme for optimisation of pipe replacements

Results. Primarily the variants of periodicity of the maintenance works were evaluated using separate indicators - energy, economical and ecological. Results of the calculations of the variants are different by their values and units, so they should be sorted out and the nondimensional values, which could be compared together, should be defined. Therefore, the equations $(1,2,3)$ for the estimation of non-dimensional values were created. 
They express the same kind results (energy, expenses or $\mathrm{CO}_{2}$ emission) in percents, ie zero value set to the minimal result and one - to the maximal result. Other values are between zero and one.

$$
\begin{aligned}
& e_{n}=1-\frac{E_{\max }-E_{n}}{E_{\max }-E_{\min }}, \\
& k_{n}=1-\frac{K_{\max }-K_{n}}{K_{\max }-K_{\min }}, \\
& c_{n}=1-\frac{C_{\max }-C_{n}}{C_{\max }-C_{\min }},
\end{aligned}
$$

$e, k, c$ - energy, economical, ecological factors; $E$, $K, C$ - energy demand, expenses, $\mathrm{CO}_{2}$ emission; subscript max - variant with maximal value; subscript min variant with minimal value; subscript $n$ - pending variant.

The variants were calculated in interval from 20 to 50 years periodicity of pipe replacement (ie it was calculated 30 variants). All calculations of DH network in Zarasai were performed for a fixed period of 50 years. The results of the calculations are presented in Fig 3. The curves of energy demand, expenses and $\mathrm{CO}_{2}$ emission are different. In standpoint of energy demand the pipes of DH network in Zarasai should be replaced every 24 years, in terms of expenses - every 33 years, and the minimal $\mathrm{CO}_{2}$ emission corresponds to the periodicity of pipe replacement of 22 years.

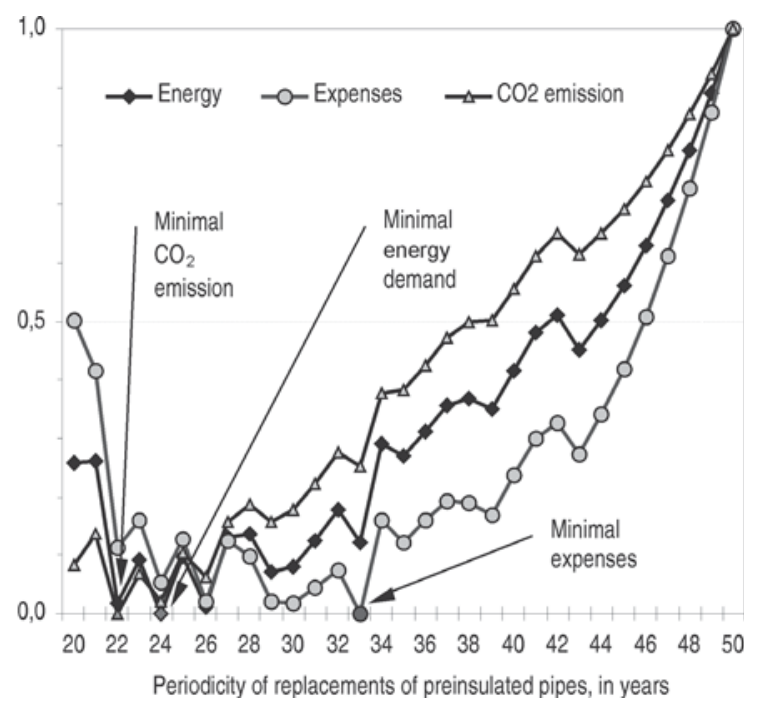

Fig 3. The best periodicity of pipe replacements depending on minimal energy demand, expenses and $\mathrm{CO}_{2}$ emission

Sharp fluctuations of the curves are related to diversity of age of the pipeline sections. If the ages of all sections were equal, the fluctuations of the results could be avoided.

For estimation of optimal periodicity of pipe replacements from all three standpoints, the $3 \mathrm{E}$ factor should be calculated. It can be set using (4) equation:

$$
3 E=e_{n} \cdot s_{e}+k_{n} \cdot s_{k}+c_{n} \cdot s_{c},
$$

$s_{e}, s_{k}, s_{c}$ - weight coefficients of energy, economical and ecological factors.

The values of weight coefficients can be chosen by regarding the purpose of the analysis. A larger coefficient is given to the factor, which is of major importance for the analysis. If the significance of all factors is the same, their weight coefficients are equal together (the sum of all coefficients should be equal to one). The best solution is the variant with a minimal $3 \mathrm{E}$ factor. In this case it was assumed that all three weight coefficients are equal together. After the variants were calculated, it was set that the optimal periodicity of pipe replacement in Zarasai DH network is 24 years (Fig 4).

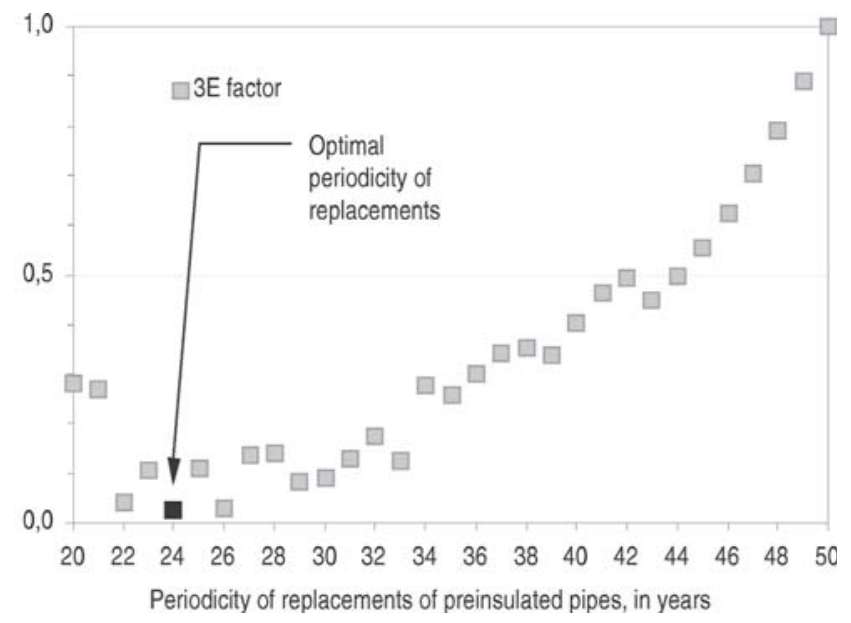

Fig 4. Optimisation using the $3 \mathrm{E}$ factor

The results of the calculations for the variants of minimal energy, economical, ecological and $3 \mathrm{E}$ factors are presented in Table 1. Thick print values indicate the minimal rates of all variants.

Table 1. Average annual energy demand, expenses and $\mathrm{CO}_{2}$ emission according to separate variants

\begin{tabular}{c|c|c|c|c}
\hline \multirow{2}{*}{$\begin{array}{c}\text { Annual } \\
\text { rates }\end{array}$} & \multicolumn{4}{|c}{ Variant } \\
\cline { 2 - 5 } $\mathrm{kWh} / \mathrm{m}^{2}$ & Energy & Economical & Ecological & $3 \mathrm{E}, \mathbf{0 7}$ \\
\hline $\mathrm{Lt} / \mathrm{m}^{2}$ & 3,48 & $\mathbf{3 , 4 3}$ & 3,53 & 3,48 \\
\hline $\mathrm{CO}_{2} \mathrm{~kg} / \mathrm{m}^{2}$ & 3,5 & 3,53 & $\mathbf{3 , 4 9}$ & 3,5 \\
\hline
\end{tabular}

\subsection{Optimisation of the thermal insulation quantity for the single family house}

In this example the purpose of research was to find such combination of the thermal insulation thicknesses in the building barriers, which leads to the minimal energy expenditures, pollutants emission and expenses during the life cycle of the building.

The object of this research is a microclimatic system of the single family house, including passive (building barriers) and active (boiler and heating system) ele- 
ments. Calculations were made for 7 different typical Lithuanian houses. The behaviour of three target functions (total energy, pollution and expenses) was investigated varying building size, configuration, number of floors, thermal insulation scheme, main construction materials, internal temperatures, windows area, duration of life cycle, type of heating system, boiler and energy source, possible rising of fuel prices etc. The optimisation procedure was performed three times for each variant: for energy, pollution and expenses. The results presented below correspond to the most representative (basic) variant, which is: single storey house with attic and basement with total area of $120 \mathrm{~m}^{2}, 4$ living persons, ceramic brick walls, concrete basement walls and pitched roof insulated by mineral wool, triple glazed windows in wooden frames, air change rate 0,8 times per hour, two pipe heating system with plate radiators, wood fired boiler, 75 years estimated life cycle, 3507 degree-days.

Methodology. In the total building life cycle energy are included: primary energy used for production of building materials and equipment, for its transport to the construction site, for construction and renovation of building and the fuel burned (even in cases of electrical heating or taking heat from district heating network) during building use to ensure a required microclimate. The determinant for this amount is the quantity of thermal insulation in building partitions. The bigger the quantity, the lesser the heat losses but more energy is needed for the production of thermal insulation. Besides, the changes in heat losses cause changes in a power (or size) of heat generator and heating devices as well as in energy needed for production of this equipment.

The aim of optimisation was to find the combination of insulation layers thickness in partitions with the minimal total energy consumed during the life cycle of a building. The formal description of this energy amount as function of multiple variables (insulation thicknesses) allowed to minimise this function using computational technique and mathematical methods [9]. Moreover, according to this principle, it was possible to replace energy expenditure for production of building materials by pollution emission per product during the production and to get the ecological optimum. In case of economical optimisation the data of energy expenditure was replaced by expenses for building materials, construction process and fuel used during the exploitation. Considering available data and research extents as pollution indicator was selected carbon dioxide $\left(\mathrm{CO}_{2}\right)$, though in an ideal case the emissions of all pollutants should be taken into account.

Main data. One of most important stage of the life cycle analysis is gathering the information about the energy required for production of building materials and equipment. However, this stage is also very complicated. This fact is mentioned in almost all literature references. The reason is the necessity to analyse either technological processes of products or input-output tables of industrial enterprises. In this work data of energy required for materials production were taken from previously made research, based on analysis of references [10]. The determination of energy embodied in different equipment is even more complicated, because the amount of this energy is not related directly to materials quantity used for production of this equipment. In this case often the input-output method is used, but for its application it is necessary to have input-output tables. As it is known, in Lithuania no such tables exist yet, so here a simplified input-output method was used, based on the so-called energy intensity of economics - ratio between the total primary energy consumed in country with its gross domestic product (GDP) [11]. The amounts of carbon dioxide emitted per unit of product were obtained using data about different sources of fuels (energy) consumed during production of this product.

Results. In order to compare the results obtained during optimisation by different criteria (energy, pollution and expenses), the resulting average insulation thickness (AIT) in building barriers was chosen as indicator. This value was calculated as weighted average, where the total area of concerned construction type was treated as the "weight". The compromised solution (3E factor) was obtained using some acceptance intervals of AIT instead of point with exact minimum (Fig 5). The width of these intervals is obtained accepting some uncertainty of target functions. The bigger uncertainty, the larger solution area appears, or vice versa. In the variant in Fig 5 , the minimal uncertainty, using which it is possible to get solution, is about $4 \%$. In this case AIT value of compromised solution is $12 \mathrm{~cm}$. Grey area shows the interval of AIT, where any of three target functions does not exceed its minimum more than $4 \%$.

Fig 6 shows the obtained minimums of the three target functions and the corresponding compromise solutions of the basic house variant in using different energy sources. Naturally, the compromised solutions are in an intermediate position. The economical optimum in case of heat from district heating network is coincident practically with requirements of the present regulation [12]. It stands to reason, because it is most likely, that the mentioned regulation was based namely on economical calculations. But it is obvious that this uniform regulation is not suitable for the houses, which used different energy source for heating. For instance, in case of using wood boiler for heating, the thermal insulation thicknesses of the building barriers should be divided by 2 . In case of electricity - conversely - insulation thicknesses should be multiplied by 1,5 . In case of ecological optimisation using electricity for heating, the optimal AIT obtained is zero. The reason of this is the fact that almost all electricity in Lithuania is produced in a nuclear power station, consequently there is no $\mathrm{CO}_{2}$ emission.

Economical optimum and corresponding present regulation [12] express, actually, the interest of the energy consumer, the aim of which is minimal financial expenses during the economical life cycle (normative return period) of the building. The interest of the state 


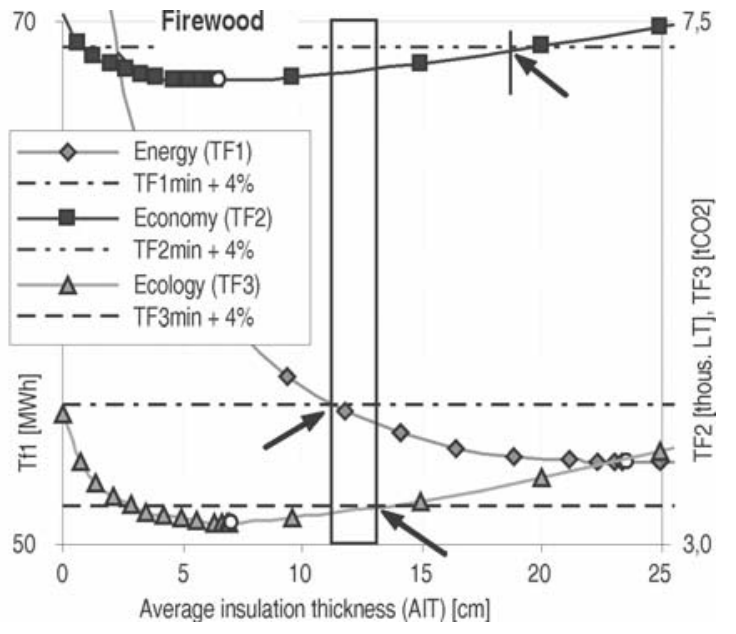

Fig 5. Curves of target functions and a compromise solution interval in using firewood for heating. Values of target functions are divided by considered duration of life cycle of building ( 75 years)

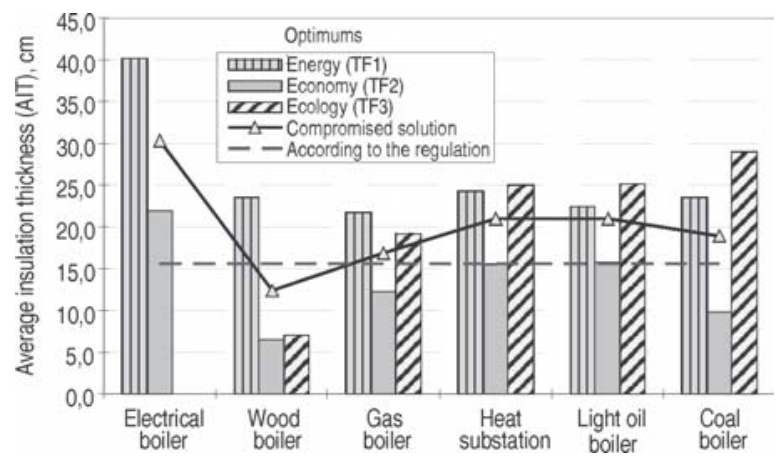

Fig 6. Minimums of the three target functions and the compromise solutions of the basic house variant in using different energy sources

in this field is slightly different (more wide) - minimal amount of imported primary energy and minimal pollution of environment during physical life cycle of the building. Admittedly, the general state interest comprises also the interests of consumer. In this situation the complex criterion (3E factor) is more suitable. Since the compromise solution differs from consumer optimum, it can be implemented only by some regulation. For instance, it can be made by correcting the above-mentioned regulation [12].

\section{Conclusions and discussion}

The case studies, illustrated in this paper, shows that solutions using energy, expenses and pollution are different, therefore application of multiple-criteria optimisation results is possible only implementing some public regulation. The $3 \mathrm{E}$ factor as optimisation criteria is more suitable for expressing interests of the state or even a larger community, rather a single consumer.
In the first example the benefits of DH network preventive maintenance, which involve security, reduction of expenditure on repairs and the ensuring of a steady supply, were investigated. Using the $3 \mathrm{E}$ factor, the optimal periodicity of pipe replacement (from energy, economy and ecology standpoints) was calculated.

The optimal thermal insulation quantity and its distribution across the envelope of a single-family house over its life cycle were examined in the second example. The optimum (optimal insulation quantity and its distribution scheme) was obtained in three cases - optimising total consumed energy, expenses and $\mathrm{CO}_{2}$ emission over the building life cycle. It was estimated that the results of these three cases differ significantly. Therefore $3 \mathrm{E}$ factor was introduced to obtain one solution.

\section{References}

1. Center for Sustainable Systems. Definition: Integrating Systems Analysis \& Sustainability. http:// css.snre.umich.edu/ 1_8_approach.htm

2. Čiuprinskas, K.; Rogoža, A. The application of $3 \mathrm{E}$ factor as sustainability expression for multi-criteria optimisation of energy systems. In: Proceedings of 6th International Conference "Energy for Buildings". Vilnius: Technika, 2004, p. $48-57$.

3. Rogoža, A. Estimation of existing district heating distribution network from the standpoint of life cycle analysis. Journal of Civil Engineering and Management, Vol IX, No 2, 2003, p. 104-109.

4. Martinaitis, V. Thermodynamical analysis model of building life cycle (Pastato gyvavimo ciklo termodinaminès analizès modelis). Monograph. Vilnius: Technika, 2001. 172 p. (in Lithuanian).

5. Zavadskas, E.; Kaklauskas, A.; Banaitienè, N. Multiple criteria analysis of the building life cycle (Pastato gyvavimo proceso daugiakriterinè analizè). Vilnius: Technika, 2001. 380 p. (in Lithuanian).

6. Šiupšinskas, G.; Rogoža, A. Planning of the modernisation of district heating system by evaluating the renovation of end users and the depreciation of heat supply network. In: Proceedings of 6th Intern Conference "Energy for Buildings". Vilnius: Technika, 2004, p. 180-189.

7. prEN 13941:2002. Design and installation of preinsulated bonded pipe systems for district heating. European Committee for Standardization, Brussels, 2002. 109 p.

8. Rogoža, A. The evaluation of district heating networks in terms of a life cycle. Summary of Doctoral Dissertation. Vilnius: Technika, 2003. 28 p.

9. Čiuprinskas, K. Energetic optimisation of thermal insulation in building barriers using numerical methods. Energetics (Energetika), No 1. Vilnius: Academia, 1999, p. 3947 (in Lithuanian).

10. Čiuprinskas, K.; Martinaitis, V. Particularities of determining primary energy needs for building materials. Statyba (now known as Journal of Civil Engineering and Management), Vol 11, No 3. Vilnius: Technika, 1997, p. 3543 (in Lithuanian). 
11. Čiuprinskas, K. Modelling of single-unit dwelling energy expenditure and optimisation of thermal insulation distribution. Summary of Doctoral Dissertation. Vilnius: Technika, 1999. 36 p. (in Lithuanian).
12. Thermal technique of envelops of the buildings (Pastatu atitvarų šiluminè technika). Regulation STR 2.05.01:1999. Vilnius: Ministry of Environment 1999. 133 p. (in Lithuanian).

\section{ENERGETINIŲ SISTEMŲ OPTIMIZAVIMAS NAUDOJANT 3E KRITERIJŲ: JO TAIKYMO PAVYZDŽIAI}

\section{A. Rogoža, K. Čiuprinskas, G. Šiupšinskas}

\section{Santrauka}

Energetinès sistemos turètų būti tiriamos atsižvelgiant ì tvariosios plètros principus. Techninès sistemos optimalumas dažniausiai vertinamas tik techniniais ir ekonominiais kriterijais. Tačiau tokio vertinimo nepakanka, kai sistemos gyvavimo ciklas yra daug ilgesnis už patikimų ekonominių prognozių laikotarpi. Šiame straipsnyje kriterijų rinkinys, reikalingas energetinei sistemai ịvertinti ir optimizuoti, buvo papildytas energiniais bei ekologiniais rodikliais ir panaudotas naujas daugiakriteris rodiklis (3E kriterijus - energinis, ekonominis, ekologinis). Šio rodiklio taikymas pateikiamas dviem pavyzdžiais: šilumos tiekimo tinklo vamzdynų atnaujinimo optimizavimu ir vienbučio gyvenamojo namo šilumos izoliacijos optimizavimu.

Raktažodžiai: energetinès sistemos, optimizavimas, daugiakriteris įvertinimas, tvarioji plètra, gyvavimo ciklas, šilumos tiekimo tinklai, šilumos izoliacija.

Artur ROGOŽA. Doctor, Assoc Prof at the Dept of Heating and Ventilation at Vilnius Gediminas Technical University (Lithuania). Research interests: analysis of district heating and gas supply systems, life cycle analysis and multiple criteria analysis of energy systems, energy audits of buildings.

Kęstutis ČIUPRINSKAS. Doctor, Assoc Prof at the Dept of Heating and Ventilation (Vilnius Gediminas Technical University, Lithuania). Research interests: analysis, modelling and optimisation of building microclimatic systems.

Giedrius ŠIUPŠINSKAS. MSc, Assistant at the Dept of Heating and Ventilation, Vilnius Gediminas Technical University, Lithuania. Area of research interests: sustainable energy planning of district heating system, process and system integration, energy audits of buildings. 